\title{
Financial Reporting Quality and Financial Performance of Quoted Banks in Nigeria
}

\author{
Abakasanga, Nse Okon \\ Department of Accounting, Faculty of Management Sciences \\ University of Port Harcourt, Choba, Port Harcourt, Nigeria \\ Prof. Ofurum, C. O. \\ Department of Accounting, Faculty of Management Sciences \\ University of Port Harcourt, Choba, Port Harcourt, Nigeria \\ Dr. Ogbonna, Gabriel N. \\ Department of Accounting, Faculty of Management Sciences \\ University of Port Harcourt, Choba, Port Harcourt, Nigeria
}

\begin{abstract}
The study examined the effect of financial reporting quality on financial performance of quoted banks in Nigeria using secondary data obtained from Nigeria stock exchange spanning from 2007 to 2016. Relevance of accounting information (measured by earnings and book value of equity predictive ability-EBVEP) and timeliness of accounting information (measured by audit report lag-ARL) were subjected to Hausman test and also regressed against performance variable: Price to earnings ratio -PER, Earnings yield -ENY and Dividend yield $-D V Y$. Findings indicate a significant positive effect of EBVEP on PER and significant negative effects on ENY and DVY implying that an increase in EBVEP increases PER but decreases ENY and DVY. Similarly, a positive significant effect of ARL is found on PER and DVY but with a negative insignificant effect on ENY, implying that an increase in ARL increases PER and DVY but decreases ENY. The study therefore confirms that accounting information is value relevant and could be used for evaluation of accounting standards as well as for the investigation of the economic consequences of new accounting standards on the performance of quoted banks in Nigeria. We recommend that policy makers such as SEC, CBN, and FRCN should look into the audit report lag of quoted financial institutions in Nigeria and formulate policies to enforce compliance with the stipulated reporting requirements. This will assist in restoring investors' confidence in financial reporting.

KEYWORDS: Financial reporting quality, Relevance, Timeliness, Financial Performance, Price/ earnings ratio, Earnings yield, Dividend yield, Nigerian Banks.

DOI: $10.7176 /$ RJFA/10-9-08

Publication date:May $31^{\text {st }} 2019$
\end{abstract}

\section{INTRODUCTION}

Financial sector is the backbone of the economy of any country. It facilitates the achievement of sustained economic growth through providing efficient monetary intermediation. As confirmed by (Jha and Hui, 2012), it promotes investment by mobilizing savings and efficiently channelling resources to productive business opportunities. Banks occupy strategic and important position in the economic activities of Nigeria by the intermediary role, accepting deposits, processing payments, issuing bank drafts and cheques, granting loans and overdrafts, brokering insurance contracts, loan syndication, giving vital investment advice, providing financial services to individual business men and various organizations in order to lubricate and sustain the economic growth of the country. Therefore, banks financial performance has attracted considerable academic and professional discourse because the overall financial performance of various firms including banks, among other institutions, determines to a large extent the economic performance of Nigeria. The market- based measures of financial performance (price to earnings ratio, earnings yield and dividend yield) are considered as proxies for banks financial performance.

The main focus of financial reporting is to provide high-quality financial information concerning economic entities which are considered useful for economic decision making. Providing high quality financial information is important because it will positively influence users of accounting information such as investors, capital providers and other stakeholders in making investment, credit, and similar resource allocation decisions thereby enhancing overall stock market efficiency ( IASB, 2008).

According to IASB, financial reporting quality is a broader concept that does not only refer to financial information, but also to disclosures, and other non-financial information useful for decision making included in the report. The essential principle of assessing the financial reporting quality is related to the quality of disclosed information in a company's financial reports. These qualitative characteristics determine the decision usefulness 
of financial information in financial reports. To achieve high-quality reporting, accounting information contained in financial reports must be relevant, faithfully represented, comparable, verifiable, timely, and understandable. Accounting information prepared with due cognisance of high quality accounting standards is expected to assist investors' optimal investment decision which will consequently reflect on the firm's market value. For the purpose of this study one fundamental quality (Relevance) and one enhancing quality (timeliness) are considered as proxies for financial reporting quality.

Relevance of accounting information released to the general public by firms directly or indirectly has a major influence on investors' perceptions of the value of the business, and both individual and institutional investors attach great importance to information in the selection of portfolios of equity securities, bonds and other investments (US code of Federal Regulations, 2004). Accounting Theory and Conceptual Frameworks explicitly stated that for information to be useful, it must be relevant to the decision-making needs of users. Information has the quality of relevance when it influences the economic decisions of users by helping them to evaluate past, present or future events or confirming, or correcting, their past evaluations. Literarily, value relevance is the ability of financial statements accounting information to capture information that is capable of influencing share value in the stock market. Barth, Beaver \& Landsman, 2001 posit that value relevance concept is all about how much of an entity's market value can be described by accounting information disclosed. According to Barth et al. (2001), test of value relevance is one approach to operationalise stated criteria of relevance and faithful representation (qualitative characteristics of accounting information) by the standards setters. Also, value relevance is one of the desirable attributes (or measures) of accounting quality (Francis, LaFond, Olsson \& Schipper, 2004). Generally, etymology of value relevance study has been traced to Ball and Brown's (1968) seminal work through which they argued that newly released useful accounting information will affect efficient capital market.

To enhance the relevance of financial reporting, accounting information must be provided in a timely basis. For accounting information to be timely, the accumulation and summarization of accounting information and its publication should be as rapid as possible to assure the availability of current information in the hands of the users. This also implies that, financial statements should be presented at frequent intervals, to reveal changes in the firm's situation, which may in turn affect the users' predictions and decisions (Sengupta, 1998).

Extreme lapses in financial reporting have given rise to high profile scandals that resulted not only in investors' losses but also in reduced confidence in the financial system. The Enron and Worldcom accounting scandals in the United States, the defunct Oceanic Bank, Spring Bank, Intercontinental bank, Afribank, Bank PHB among others, the arrest of some banks Chief Executives by the Economic and Financial Crimes Commission (EFCC) and the Cadbury crisis all relate to deception and accounting information failures in financial reporting. Banks' reports to the $\mathrm{CBN}$ and investors often were inaccurate, incomplete and late, depriving the $\mathrm{CBN}$ of the right information to effectively supervise the industry and depriving investors of information required in making informed investment decisions.

Extant studies relating to the subject matter in Nigeria use primary data and were carried out in capital extensive industries like the manufacturing sector as such nature of industry, choice of accounting policies and regulatory requirements disparities necessitate a new study on the subject. The aim of this study is to empirically investigate the effect of financial reporting quality on the financial performance of quoted banks in Nigeria.

\section{LITERATURE/THEORETICAL UNDERPINNING}

\subsection{THEORETICAL FRAMEWORK}

The theories which provide support for this study includes Value relevance theory, Efficient market Hypothesis, Residual income valuation model and Signalling theory.

2.1.1 Value relevance theory: The value relevance theory is based on the idea that accounting information is useful in determining the value of decision made by users of accounting information, e.g investment values. Beaver (1968) defined value relevance of accounting information as the capacity of accounting information in describing accounting values.

2.1.2 Residual income valuation model: this is model which assumes that cost of equity should be properly accounted for. The word residual refers to any opportunity costs in excess which measured as compared to book 
value of the shareholders' equity and the income that a firm generates after accounting for the true cost of capital then the residual income. It is used in predicting stock prices

2.1.3 Market efficiency theory: The market efficiency theory states that assets prices fully reflect all relevant available information. A direct implication is that it is impossible to "beat the market" consistently on a riskadjusted basis since market prices should only react to new information (en.m.Wikipedia.org). In efficient markets, it is expected that when information arises it is reflected quickly into the prices of stocks. When the price of a financial asset reflects all the relevant information that is available about the intrinsic value of an asset, the market is termed an efficient market.

2.1.4 Signaling Theory: The signaling theory also referred to as the information content hypothesis assumes that corporate announcements are hypothesized to have information content, for example, managers use cash dividend announcement to signal changes in their expectation about the future prospect of the company when the markets are imperfect.

\subsection{CONCEPTUAL FRAMEWORK}

The conceptual framework below is developed to investigate the relationship between financial reporting quality and financial performance. In this conceptual framework, financial reporting quality (proxied by relevance and timeliness of accounting information) and financial performance (proxied by price earnings ratio, earnings yield and dividend yield) are the predictor and criterion variables. The present study therefore tries to cover the gap by providing a basis for good judgment of the effect of financial reporting quality and financial performance.

Operational Framework of Financial Reporting Quality and Financial Performance of Quoted banks in Nigeria

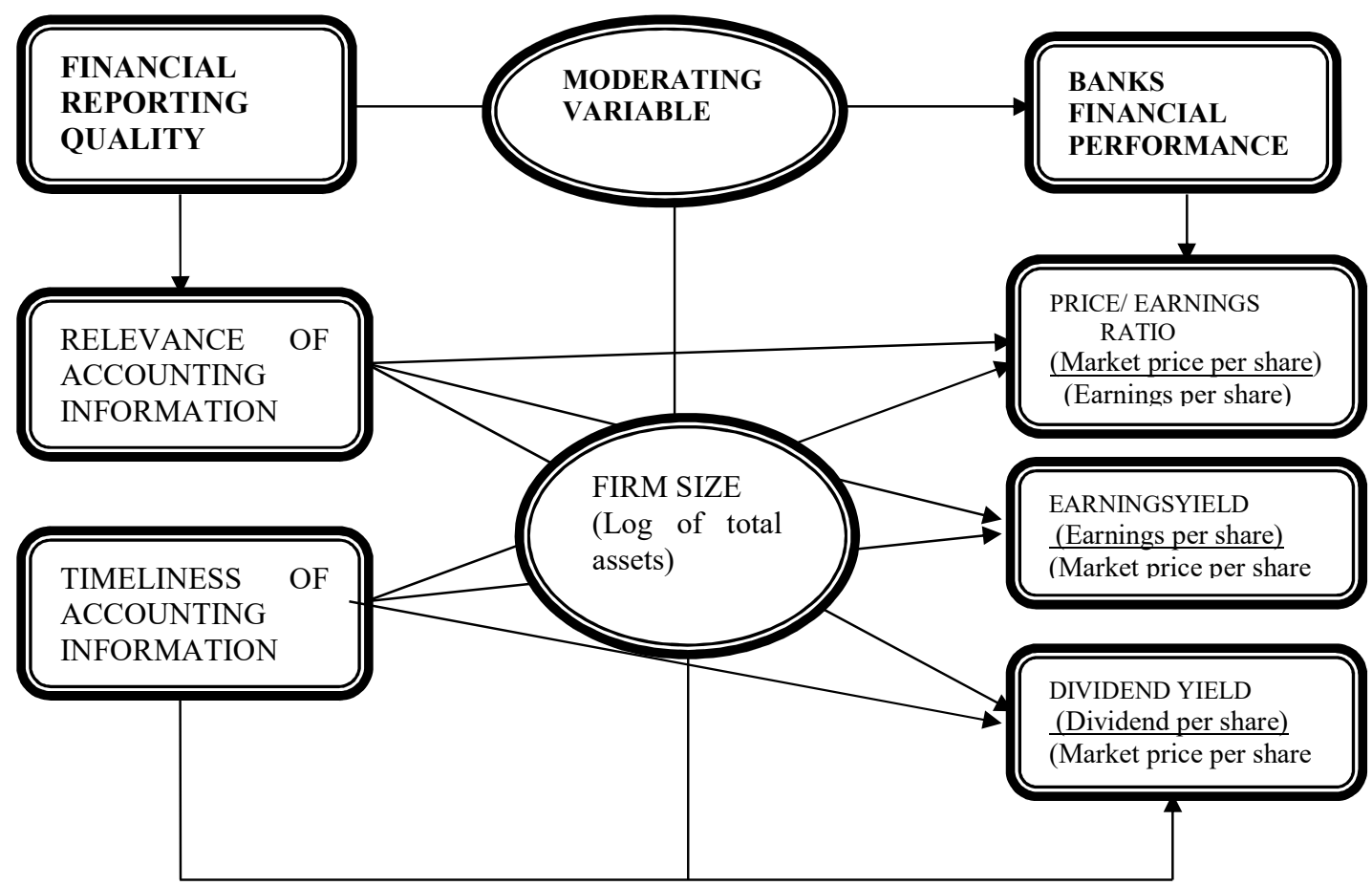

Fig 1.1: Researcher's Design

Price to Earnings Ratios (PER): PE ratio shows the number of times the share price covers the earnings per share over a year. It may also be interpreted as how much an investor pays for every $\$ 1$ naira the bank earns. The higher the $\mathrm{P} / \mathrm{E}$ ratio, the more the market is willing to pay for every unit of earnings. Firms with high $\mathrm{P} / \mathrm{E}$ ratios are more likely to be considered "risky" investments than those with low $\mathrm{P} / \mathrm{E}$ ratios, since a high $\mathrm{P} / \mathrm{E}$ ratio implies high investors' expectations. 
Earnings Yield (ENY): Earnings yield are the earnings per share for the most recent 12-months period divided by the current market price per share. It is the inverse of the price/ earnings ratio showing the percentage of each naira invested in the stock that was earned by the company.

Dividend Yield: Dividend yield is a ratio which indicates how much a company pays out in dividend each year relative to its share price. Also known as dividend-price ratio is calculated by dividing the naira value of dividends paid in a given year per share of stock by the naira value of one share of stock. Dividend yield is useful in determining earnings on investment (shares) considering only the returns in the form of total dividends declared by the company during the year.

\subsection{EMPIRICAL REVIEW}

Plenitudes of empirical investigations have established nexus of accounting information quality with bank financial performance across the globe. Pervan (2012) used a sample of 97 corporations to analyze the value relevance of accounting information on the capital markets of Southeast Europe. The research findings showed that accounting information is value relevant on all the observed markets. Glezakos, Mylonakis, and Kafouros (2012) studied the impact of earnings and book value of equity on stock prices formulation. Using a sample of 38 companies listed in the Athens Stock Market during the 1996-2008 periods, the results concluded that the joint explanatory power of the measured parameters in the formation of stock prices increases over time. The study further examined that the impact of earnings has diminished, compared to book value over time. In a domestic study, Abubakar (2011) studied the influences of accounting information on the share price of the firms. The study finds an insignificant correlation between share price and accounting information proxies which may be attributable to other factors other than accounting information. Uwuigbe, et al. (2017) examined the impact of IFRS adoption on the value relevance of accounting information. With a sample of 10 companies within the consumer industry of the Nigerian economy between 2010 and 2013, the study found out that the value relevance of accounting information has improved after the adoption of IFRS, with EPS showing a stronger explanatory power.

Olugbenga and Atanda (2014) studied the value relevance of accounting information of quoted companies in Nigeria. The outcome of the study revealed that accounting information on quoted companies in Nigeria is value relevant. Also, Oyerinde (2011) investigated the value relevance of accounting data in the stock market. By using primary and secondary (panel cross-sectional and time-series) data, information content of various accounting numbers (i.e. book value, earnings and dividends) were measured through OLS, Random Effects Model (REM), and Fixed Effects Model (FEM). The study focused on 68 NSE listed companies for the period of 2002 to 2008. The findings of the study show that significant relationship exist between accounting information and share prices of the listed firms. Dabor and Mohammed (2015) examined the determinants of audit report timeliness for listed joint stock companies in Saudi Arabia. The findings showed a negative relationship between audit report timeliness and firm performance. Salim (2012) studied the relationship between bank size and financial performance of commercial banks in Kenya. The findings of the study established strong correlations between all the studied factors of bank size.

\section{METHODOLOGY}

\section{DATA}

The population consists of all commercial banks in Nigeria. The purposive sampling technique was adopted to select the fifteen (15) quoted banks for the purpose of investigation. Financial statements of the sampled banks between 2007 and 2016 were used for the study.

\section{VARIABLES}

\section{Independent Variables}

Financial reporting quality was measured by Relevance and Timeliness. Relevance is measured as (Earnings book value of equity predictive ability -EBVEP) using the price model by Ohlson (1995), the choice of this model is motivated by its ability to yield an unbiased earnings coefficient since the stock price reflects the cumulative effects of earnings information and the market value is related to both the book value and the accounting earnings (Kothari \& Zimmerman, 1995); while timeliness is measured by audit report lag (ARL)

The modified Ohlson model is stated below:

$\mathrm{MV}_{\text {it }}=\alpha+\beta_{1} \mathrm{EPS}_{\text {it }}+\beta_{2} \mathrm{BV}_{\text {it }}+\varepsilon$

Where:

$\mathrm{MV}_{\mathrm{it}}$ is the market value per share of firm $\mathrm{i}$ in period $\mathrm{t}$, 
EPS $_{\mathrm{it}} \quad$ is earnings per share of firm $\mathrm{i}$ in period $\mathrm{t}$,

$\mathrm{BV}_{\mathrm{it}}$ is the book value per share of equity of firm $\mathrm{i}$ in period $t$,

$\alpha$ - intercept,

$\beta_{1}$ and $\beta_{2}$ - regression coefficients with unknown values, and

$\varepsilon-\quad$ error term.

The explanatory power of each variable is measured as:

$\mathrm{MV}_{\mathrm{it}}=\alpha+\beta_{1} \mathrm{EPS}_{\mathrm{itt}}+\varepsilon_{\mathrm{it}}$

$\mathrm{MV}_{\mathrm{it}}=\alpha+\beta_{2} \mathrm{BVE}_{\mathrm{itt}}+\varepsilon_{\mathrm{it}}$

Decision rule: If adjusted $\mathrm{R}^{2}$ is significantly different from zero then accounting information is said to be value relevant and hence is useful in predicting future earnings, confirming or correcting past predictions.

\section{Dependent Variable}

The dependent variable in the model is financial performance and is proxied by Price to earnings ratio (PER), Earnings yield (ENY) and Dividend yield (DVY).

The price earnings ratio expresses the market price of the shares as the number of years of its current earnings.

PER $=\underline{\text { Market price per share }}$

Earnings per share

Earnings yield are the earnings per share for the most recent 12-months period divided by the current market price per share.

\section{ENY $=$ Earnings per share \\ Market price per share}

Dividend yield is calculated by dividing the naira value of dividends paid in a given year per share of stock by the naira value of one share of stock.

\section{DVY $=$ Dividend per share}

\section{Market price per share}

\section{Moderating Variable}

Firm size (FS) is measured as the natural logarithm of book value of total assets.

\section{MODEL SPECIFICATION}

Three econometric models were constructed to determine the effect of the independent (predictor) variable on the dependent (criterion) variable in the study. The three proxies of the dependent variable (financial performance): price earnings ratio, earnings yield and dividend yield were captured in the models viz-a-viz contemporaneous predictor variable consisting of earnings and book value of equity as well as a moderating variable of firm size to evaluate the effect of financial reporting quality on financial performances of quoted banks in Nigeria.

Stemming from the conceptual framework in figure 1, the functional form of the models is stated below:

$\begin{array}{lll}\mathrm{FP} & = & \mathrm{f}(\text { EBVEP, ARL, FSIZ) } \\ \mathrm{Fp} & = & \mathrm{PER}, \text { ENY, DVY } \\ \mathrm{PER} & = & \mathrm{f}(\text { EBVEP, ARL, FSIZ) } \\ \text { ENY } & = & \mathrm{f}(\text { EBVEP, ARL, FSIZ) } \\ \text { DVY } & = & \mathrm{f}(\text { EBVEP, ARL, FSIZ) }\end{array}$

From functional relationship, econometric models are specified thus:

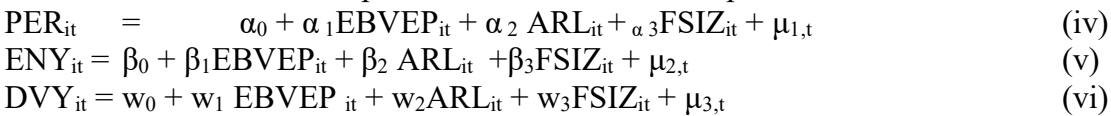

Where:

$\mathrm{PER}=$ Price earnings ratio measured as the ratio of the current market price of share to its EPS 
ENY = Earnings yield measured as the ratio of the EPS to the current market price

DVY $=$ Dividend yield measured as the ratio of the DPS to the current market price

$\mathrm{EBVEP}=$ Earnings and book value of equity predictive ability (measuring RVAI)

$\mathrm{ARL} \quad=$ Audit Report Lag (measuring TMAI).

FSIZ $=$ Firm size measured by natural logarithm of total assets while:

$\mathrm{i} \quad=$ number of banks

$\mathrm{t}=$ period covered in the study

$\alpha_{0}, \beta_{0}, w_{0}=$ intercepts or constant regression coefficients

$\alpha_{1}, \beta_{1}, \mathrm{w}_{1}=$ slope coefficients or coefficient of intercepts

$\mu_{1, \mathrm{t}} \quad=\quad$ error term

\section{RESULTS/FINDINGS}

\begin{tabular}{|lcccccc|}
\hline Statistics & PER & ENY & DIVY & RVAI & TMAI & FSIZ \\
\hline & & & & & & \\
Mean & 18.33245 & -0.513068 & 0.079551 & 0.092547 & 87.73469 & 27.45727 \\
Median & 6.100000 & 0.115000 & 0.056000 & -1.677479 & 83.00000 & 27.57397 \\
Maximum & 932.0000 & 35.36000 & 1.102000 & 36.96757 & 256.0000 & 30.51824 \\
Minimum & 29.90000 & -126.3750 & 0.000000 & -10.27049 & 17.00000 & 22.19175 \\
Std. Dev & 78.49516 & 15.65709 & 0.134589 & 9.170925 & 33.47077 & 1.016747 \\
Skewness & 10.87794 & -6.161360 & 5.994070 & 1.821668 & 1.642286 & -0.894527 \\
Kurtosis & 126.6499 & 51.00771 & 44.58900 & 6.971263 & 8.023972 & 6.947301 \\
Jarque-Bera & 96546.09 & 15046.61 & 11474.33 & 177.8996 & 220.6759 & 115.0391 \\
p-value & 0.000000 & 0.000000 & 0.000000 & 0.000000 & 0.000000 & 0.000000 \\
Obs & 150 & 150 & 150 & 150 & 150 & 150 \\
\hline
\end{tabular}

\section{Table 1: Descriptive Summary of the Data}

Source: Researcher's estimation using E-views 10.0 output

The descriptive statistics, it is observed that PER has an average value of 18.332 with maximum and minimum values of 932.0 and -29.90 respectively. The standard deviation stood at 78.49516 which is high and also looking at the difference between the maximum and minimum values suggest some substantial deviations of the PER for the firms in the sample from the mean. The average ERNY is -0.513068 with a maximum value of 35.360 and minimum value of -126.3750 respectively. The standard deviation stood at 15.657 which is high and also looking at the difference between the maximum and minimum values suggest some substantial deviations of the ERNY for the firms in the sample from the mean. DIVY has a mean of $0.079551 \mathrm{k}$ with maximum and minimum values of 1.102000 and minimum of 0.00 respectively. The standard deviation which describes the extent of dispersion of the mean stood at 0.134 which is quite benign and suggests some level of clustering of DIVY around the mean. This implies that PER varies significantly across the banks. RVAI has a mean value of 0.0925 with maximum and minimum values of 36.96757 and -10.27049 respectively. The standard deviation stood at 9.1709 indicating the extent of dispersion in distribution. The average TMAI for the banks in the sample is about 87 days with maximum and minimum lags of 256 days and 17 days respectively with a standard deviation of 33.47 indicating the extent of dispersion in distribution. The mean value for FIRMSIZE stood at 27.45727 with maximum and minimum values of 30.5182 and 22.19175 respectively with a standard deviation of 1.016747 . The Jacque-bera statistics for all the variables reveals that the series are normally distributed given that the probability values for the J.B statistics are all less than 0.05 . This implies the absence of significant outliers in the data

The results of analysis of correlation between the variables of study are indicated on the table below:

\begin{tabular}{|c|c|c|c|c|c|c|}
\hline & FIRMSIZE & DIVY & ENY & PER & RVAI & TMAI \\
\hline FIRMSIZE & 1 & & & & & \\
\hline DVY & -0.02634 & 1 & & & & \\
\hline ENY & 0.050123 & 0.02608 & 1 & & & \\
\hline PER & -0.08285 & -0.082330 & 0.00852 & 1 & & \\
\hline RVAI & -0.01472 & -0.23522 & -0.0311 & 0.216837 & 1 & 1 \\
\hline TMAI & -0.211517 & 0.063628 & 0.06321 & 0.15825 & -0.1209 & \\
\hline
\end{tabular}

Table 2: Correlation Analysis

Source: Researcher's estimation using E-views 10. 
Table 2 shows the correlation statistics for the variables and as observed we examined the correlations between the dependent variables and the set of independent variables. We find that RVAI is positively correlated with $\operatorname{ENY}(\mathrm{r}=0.0501)$ but negatively correlated with $\mathrm{DVY}(\mathrm{r}=-0.0263)$ and $\operatorname{PER}(\mathrm{r}=-0.0828)$, while TMAI is positively correlated with $\mathrm{ENY}(\mathrm{r}=0.06321), \mathrm{DVY}(\mathrm{r}=0.0636)$ and $\mathrm{PER}(\mathrm{r}=0.158)$. The correlation coefficients imply that positive correlations indicate that a rise in one variable will be associated with an increase in the other variable and vice-versa. However, correlations are limited in their inferential abilities as they do not necessarily imply causality in a strict sense.

\subsection{Test of Hypotheses}

Ho1: Relevance of accounting information does not significantly affect price earnings ratio of quoted banks in Nigeria.

\begin{tabular}{|c|c|c|c|c|}
\hline & Aprorisign & $R E$ & $F E$ & $F E$ \\
\hline \multirow{9}{*}{$R V A I$} & & $18.0358^{*}$ & 18.1144 & 21.6762 \\
\hline & & $(6.7237)$ & $(0.6540)$ & $(26.5810)$ \\
\hline & & $\{0.0081\}$ & $\{0.000\}$ & $\{0.4163\}$ \\
\hline & & 1.86512 & $0.26491 *$ & $0.30159^{*}$ \\
\hline & & $(1.51103)$ & $(0.1217)$ & $(0.1287)$ \\
\hline & & $\{0.2213\}$ & $\{0.0313\}$ & $\{0.0206\}$ \\
\hline & & & & -0.12671 \\
\hline & & & & $(0.9679)$ \\
\hline & & & & $\{0.8960\}$ \\
\hline \multicolumn{5}{|c|}{ Model Parameters } \\
\hline$R^{2}$ & & 0.0473 & 0.267 & 0.2753 \\
\hline $\operatorname{Adj} R^{2}$ & & 0.0407 & 0.1844 & 0.1867 \\
\hline F-Stat & & 7.2913 & 3.231 & 3.1099 \\
\hline$P(f$-stat $)$ & & 0.0077 & 0.000 & 0.000 \\
\hline D.W & & 2.20 & 2.1 & 2.3 \\
\hline \multicolumn{5}{|c|}{ Model Diagnostics } \\
\hline Hausman & & & 0.0423 & \\
\hline $\begin{array}{l}B \text { - } G \text { for serial } \\
\text { corr. }\end{array}$ & 0.0973 & & & \\
\hline $\begin{array}{c}B-P-G \quad \text { for } \\
\text { Hetero. }\end{array}$ & 0.163 & & & \\
\hline Ramsey Test & 0.0962 & & & \\
\hline
\end{tabular}

Table 3: The effect of RVAI on PER

Source: Researchers compilation (2018), ( ) are standard errors; \{\} are p-values, ${ }^{*}$ sig at 5\%

From the above table, the $p$-value of the Hausman test statistic (0.0423) indicates that the RE method may give bias and inconsistent estimators when compared to FE model and hence the FE estimation is preferred. As shown in the results, the $\mathrm{R}^{2}$ for the FE model is 0.267 which implies that the model explains about $26.7 \%$ of the systematic variations in the dependent variable with an adjusted value of $18.4 \%$. The F-stat is 3.231 (pvalue $=0.00$ ) is significant at $5 \%$ and indicate that the hypothesis of a significant linear relationship between the dependent and independent variables cannot be rejected.

The analysis of coefficients reveals that the effect of RVAI on PE-ratio is positive (0.2649) and significant at 5\% $\{\mathrm{p}=0.0313\}$ at $5 \%$. With this, the null hypothesis of no significance effect of relevance of accounting information on price earnings ratio is rejected.

Ho2: Relevance of accounting information does not have a significant effect on earnings yield of quoted banks in Nigeria. 


\begin{tabular}{c|c|cc|c}
\hline & Aprorisign & $R E$ & $F E$ & $F E$ \\
\hline \multirow{3}{*}{ RVAI } & & $0.4276^{*}$ & $-0.4276^{*}$ & 0.6727 \\
& & $(1.79675)$ & $(0.0343)$ & $(1.0949)$ \\
& & $\{0.8122\}$ & $\{0.000\}$ & $\{0.5400\}$ \\
& & -0.05891 & $-0.00670^{*}$ & $-0.0054^{* *}$ \\
FSIZ & $(0.11286)$ & $(0.0026)$ & $(0.0032)$ \\
& & $\{0.6025\}$ & $\{0.0102\}$ & $\{0.0928\}$ \\
& & & & -0.40225 \\
& & & & $(0.0395)$ \\
& & & & $\{0.3100\}$ \\
\hline
\end{tabular}

Model Parameters

\begin{tabular}{|c|c|c|c|c|}
\hline$R^{2}$ & & 0.0011 & 0.1438 & 0.145 \\
\hline $\operatorname{Adj} R^{2}$ & & -0.0056 & 0.0479 & 0.0415 \\
\hline$F$-Stat & & 0.1695 & 1.500 & 1.4009 \\
\hline$P(f$-stat $)$ & & 0.6811 & 0.113 & 0.1506 \\
\hline D. $W$ & & 2.17 & 2.3 & 2.3 \\
\hline $\begin{array}{l}B-G \text { for serial } \\
\text { corr. }\end{array}$ & 0.893 & & & \\
\hline $\begin{array}{ll}B-P-G & \text { for } \\
\text { Hetero. } & \\
\end{array}$ & 0.554 & & & \\
\hline Ramsey Test & 0.421 & & & \\
\hline
\end{tabular}

Table 4: The effect of RVAI on ENY

Source: Researchers compilation (2018), ( ) are standard errors; \{\} are p-values, ${ }^{*}$ sig at 5\%

The $p$-value of the Hausman test statistic (0.0046) indicates that the RE method may give bias and inconsistent estimators when compared to FE model and hence the FE estimation is preferred. As shown in the results, the $\mathrm{R}^{2}$ for the FE model is 0.1438 which implies that the model explains about $14.38 \%$ of the systematic variations in the dependent variable with an adjusted value of $4.15 \%$.

The analysis of coefficients reveals that the effect of RVAI on Earnings Yield is negative $(-0.00670)$ and significant at $5 \%\{\mathrm{p}=0.0012\}$. This leads us to reject the null hypothesis of no significance effect of relevance of accounting information on Earnings yield.

\section{Ho3: Relevance of accounting information does not have a significant effect on dividend yield of quoted banks in Nigeria.}

From the table below, the $p$-value of the Hausman test statistic (0.0314) indicates that the RE method may give bias and inconsistent estimators when compared to FE model and hence the FE estimation is preferred. As shown in the results, the $\mathrm{R}^{2}$ for the FE model is 0.1732 which implies that the model explains about $17.32 \%$ of the systematic variations in the dependent variable. The F-stat is 1.8722 ( $\mathrm{p}$ value $=0.0312$ ) is significant at $5 \%$ and suggest that the hypothesis of a significant linear relationship between the dependent and independent variables cannot be rejected.

The analysis of coefficients reveals that the effect of RVAI is negative (-0.0041) and significant at 5\% $\{\mathrm{p}=0.0067\}$. The result implies that the relevance of accounting information is significant factor influencing dividend yield though the negative sign of the variable does not conform to apriori expectation. With this, the null hypothesis of no significance effect of relevance of accounting information on Dividend yield is rejected. 


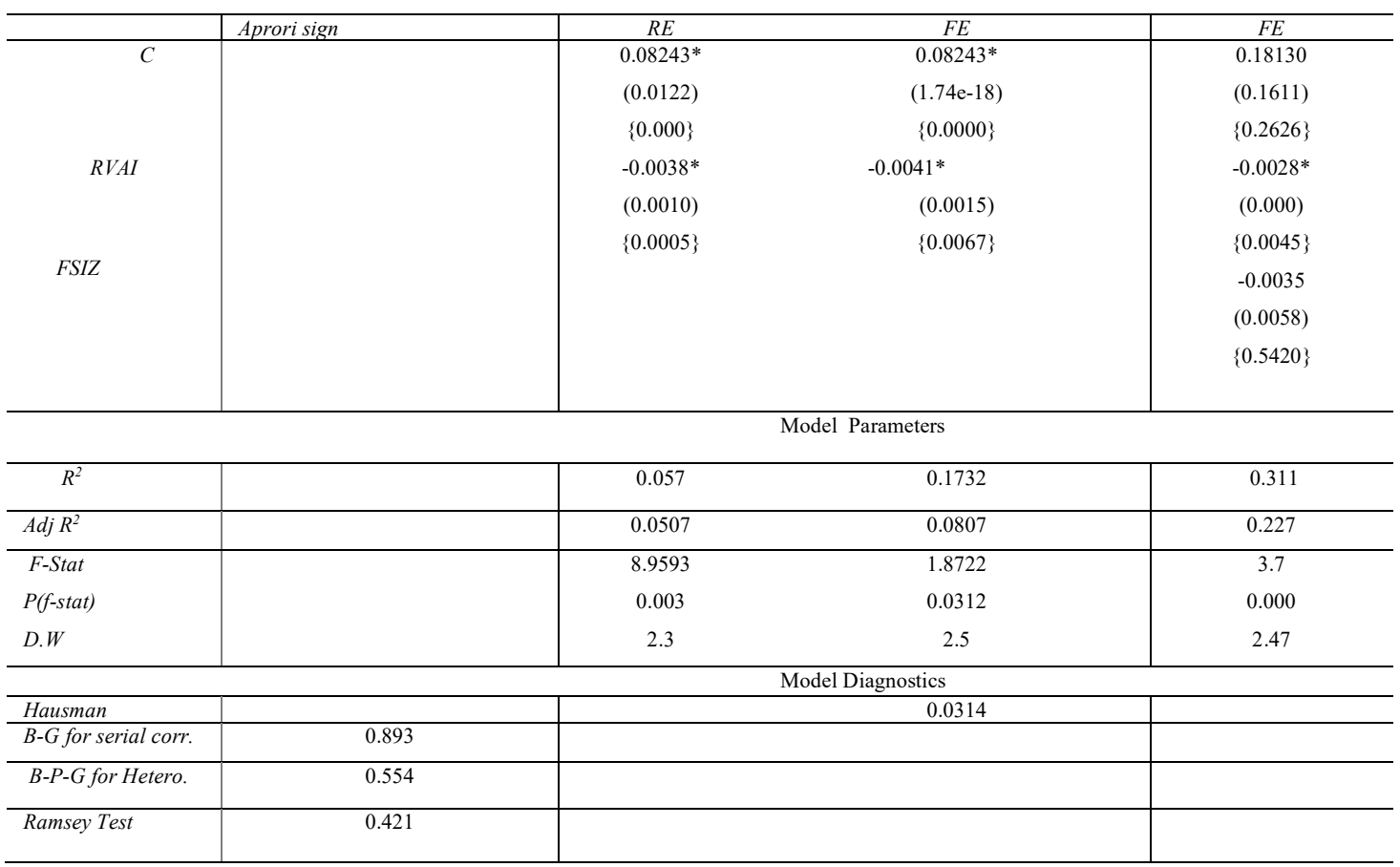

\section{Table 5: The effect of RVAI on DVY}

Source: Researchers compilation (2018), ( ) are standard errors; \{\} are p-values, ${ }^{*}$ sig at 5\%

Ho4: Timeliness of accounting information does not have a significant effect on price earnings ratio of quoted banks in Nigeria.

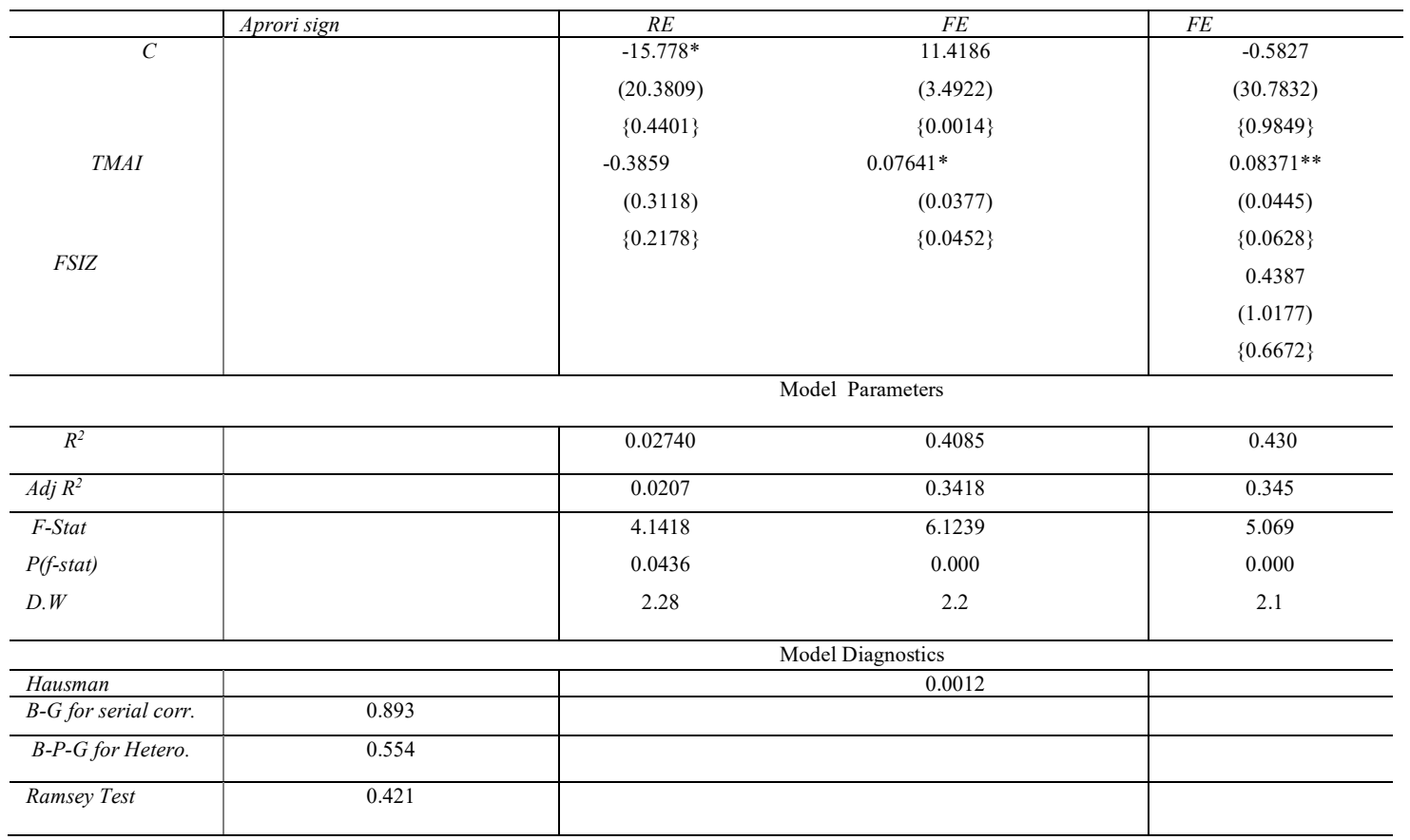

Table 6: The effect of TMAI on PER

Source: Researchers compilation (2018), ( ) are standard errors; \{\} are p-values, $*$ sig at 5\% 
The $p$-value of the Hausman test statistic (0.0012) indicates that the RE method may give bias and inconsistent estimators when compared to FE model and hence the FE estimation is preferred. As shown in the results, the $\mathrm{R}^{2}$ for the FE model is 0.4085 which implies that the model explains about $40.85 \%$ of the systematic variations in the dependent variable with an adjusted value of $34.18 \%$. The F-stat is 6.123 (p-value $=0.00$ ) is significant at $5 \%$ and suggest that the hypothesis of a significant linear relationship between the dependent and independent variables cannot be rejected.

The analysis of coefficients reveals that the effect of TMAI on PER is positive (0.0764) and significant at $5 \%$ $\{\mathrm{p}=0.0337\}$. This leads us to reject the null hypothesis of no significance effect of timeliness of accounting information on price earnings ratio.

Ho5: Timeliness of accounting information does not have a significant effect on earnings yield of quoted banks in Nigeria.

\begin{tabular}{c|c|cc|c}
\hline & Aprorisign & $R E$ & $F E$ & $F E$ \\
\hline \multirow{3}{*}{$C$} & & -2.90714 & $-0.41571^{*}$ & 2.1088 \\
& & $(4.8271)$ & $(0.01078)$ & $(1.4582)$ \\
& & $\{0.5479\}$ & $\{0.000\}$ & $\{0.1520\}$ \\
& & 0.02804 & $-0.0001 *$ & -0.0001 \\
& & $(0.03471)$ & $(0.0012)$ & $(0.0013)$ \\
& & $\{0.4204\}$ & $\{0.9113\}$ & $\{0.9264\}$ \\
& & & & $-0.09185^{* *}$ \\
& & & & $(0.0515)$ \\
& & & & $\{0.0770\}$ \\
\hline
\end{tabular}

Model Parameters

\begin{tabular}{|c|c|c|c|c|}
\hline$R^{2}$ & & 0.0038 & 0.1285 & 0.131 \\
\hline $\operatorname{Adj} R^{2}$ & & 0.0029 & 0.030 & 0.0258 \\
\hline$F$-Stat & & 0.5656 & 1.317 & 11.245 \\
\hline$P(f$-stat $)$ & & 0.4536 & 0.199 & 0.1 \\
\hline D.W & & 2.16 & 2.2 & 2.3 \\
\hline $\begin{array}{l}B-G \text { for serial } \\
\text { corr. }\end{array}$ & 0.813 & & & \\
\hline $\begin{array}{ll}B-P-G & \text { for } \\
\text { Hetero. } & \\
\end{array}$ & 0.079 & & & \\
\hline Ramsey Test & 0.901 & & & \\
\hline
\end{tabular}

Table 7: The effect of TMAI on ENY

Source: Researchers compilation (2018), ( ) are standard errors; \{\} are p-values, $*$ sig at 5\%

The $p$-value of the Hausman test statistic (0.008) indicates that the RE method may give bias and inconsistent estimators when compared to FE model and hence the FE estimation is preferred. As shown in the results, the $\mathrm{R}^{2}$ for the FE model is 0.1285 which implies that the model explains about $12.85 \%$ of the systematic variations in the dependent variable with an adjusted value of $3.0 \%$.

The analysis of coefficients reveals that the effect of TMAI on Earnings Yield is negative (-0.0001) though not significant at $5 \%\{\mathrm{p}=0.9113\}$. This leads us not to reject the null hypothesis of no significance effect of timeliness of accounting information on earnings yield.

Ho6: Timeliness of accounting information does not significantly affect dividend yield of quoted banks in Nigeria. 


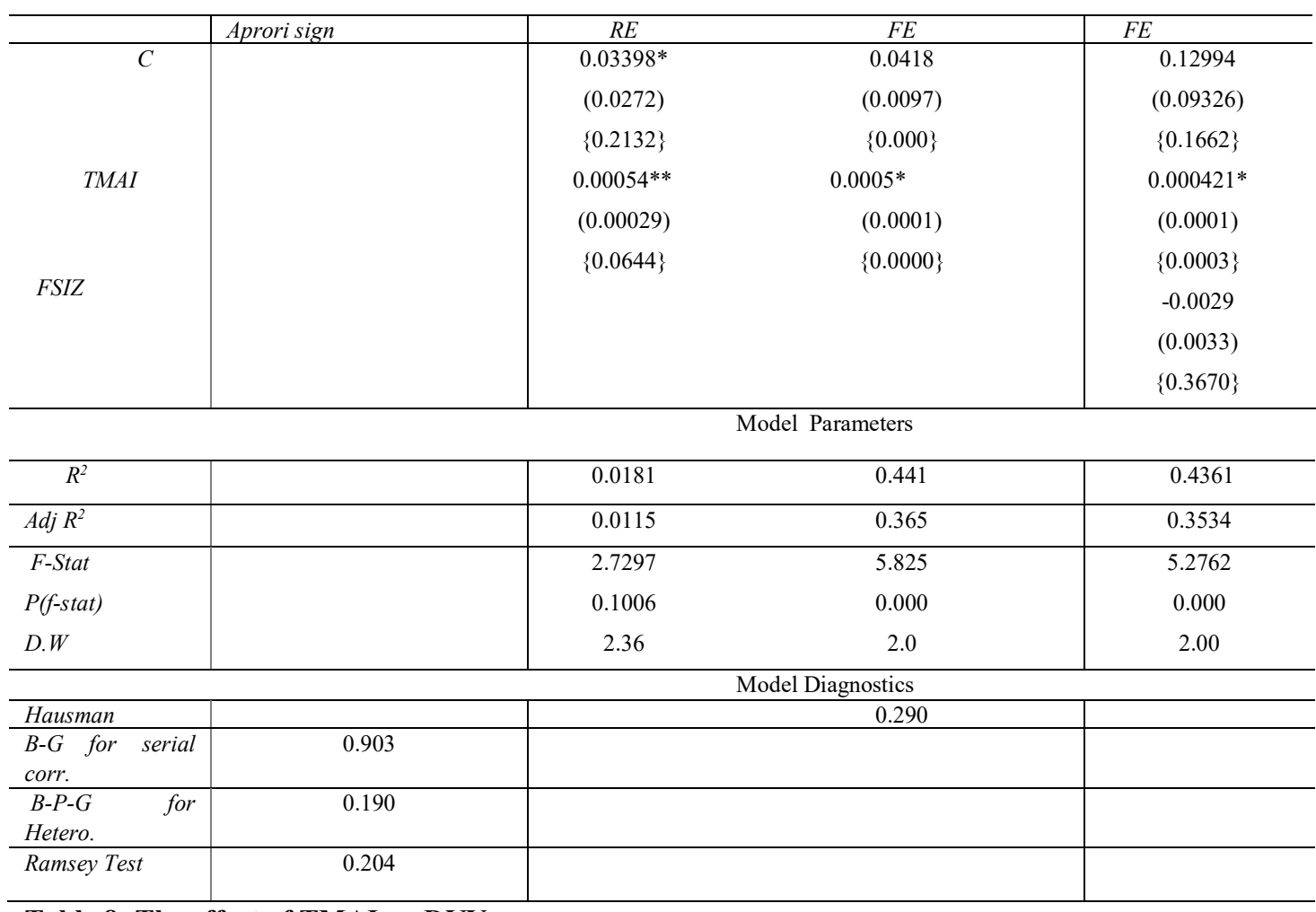

Table 8: The effect of TMAI on DVY

Source: Researchers compilation (2017), ( ) are standard errors; \{\} are p-values, * sig at 5\%

The $p$-value of the Hausman test statistic (0.0290) indicates that the RE method may give bias and inconsistent estimators when compared to FE model and hence the FE estimation is preferred. As shown in the results, the $\mathrm{R}^{2}$ for the FE model is 0.441 which implies that the model explains about $44.1 \%$ of the systematic variations in the dependent variable with an adjusted value of $36.5 \%$. The F-stat is 5.825 ( $\mathrm{p}$ value $=0.00$ ) is significant at $5 \%$ and suggest that the hypothesis of a significant linear relationship between the dependent and independent variables cannot be rejected.

The analysis of coefficients reveals that the effect of TMAI is positive $(0.0005)$ and significant at $5 \%\{\mathrm{p}=0.000\}$ at $5 \%$. This leads us to reject the null hypothesis of no significance effect of timeliness of accounting information on dividend yield.

Ho7: Firm size does not significantly moderate the relationship between accounting information quality and financial performance of quoted banks in Nigeria.

Introducing firm size as a moderating variable, the result shows that the $\mathrm{R}^{2}$ for the model rises slightly to $27 \%$ and the impact coefficient of RVAI increases to 0.302 and still maintains its statistically significant impact on PE-ratio at $5 \%(\mathrm{p}=0.0206)$ though the firm size coefficient is negative $(-0.1267)$ and not statistically significant $(\mathrm{p}=0.8960)$ at $5 \%$. This implies that firm size negatively and insignificantly moderates the effect of RVAI on PER. For the effect of RVAI on ENY, the result shows that the $\mathrm{R}^{2}$ for the model rises to $14.5 \%$ and the impact coefficient of RVAI drops from -0.00670 to -0.0054 and statistically significant at $10 \%(\mathrm{p}=0.0928)$ and though the firm size impact coefficient is negative $(-0.40225)$ it is however not statistically significant $(\mathrm{p}=0.3100)$ at $5 \%$. Similarly, the result the effect of RVAI on DVY is still significant $(\mathrm{p}=0.0045)$ and the negative direction is also sustained $(-0.0028)$ though reduced when compared to the initial coefficient with the presence of firm size. The firm size variable did not however show any significant influence on dividend yield. This leads us not to reject the null hypothesis of no significant effect of firm size on the relationship between relevance of accounting information and financial performance of quoted banks in Nigeria. 
For the effect of TMAI on PER, the result shows that the $\mathrm{R}^{2}$ for the model rises to $43 \%$ and the impact coefficient of TMAI also moved higher to 0.083 from 0.076 and statistically significant at $10 \%(\mathrm{p}=0.0628)$ and though the firm size impact coefficient is positive (0.4387) it is however not statistically significant $(\mathrm{p}=0.6672)$ at $5 \%$. Also FSIZ moderating the effect of TMAI on ENY, the result shows that the $\mathrm{R}^{2}$ for the model rises very slightly to $13.1 \%$ and the F-stat is 11.245 (p-value $=0.00$ ) is significant at $5 \%$. The impact coefficient of TMAI is strongly stable and remains statistically insignificant at $5 \%(\mathrm{p}=0.9264)$ and though the firm size impact coefficient is negative $(-0.09185)$ it is however statistically significant $(\mathrm{p}=0.0770)$ at $10 \%$. Similarly, for the effect of TMAI on DVY, the result shows that the $\mathrm{R}^{2}$ for the model drops slightly to $43.61 \%$ and the effect of TMAI maintains its statistical significance at $5 \%(\mathrm{p}=0.0003)$ though the firm size variable shows a negative ($0.0029)$ but not statistically significant influence $(\mathrm{p}=0.3670)$ at $5 \%$ on dividend yield. This leads us not to reject the null hypothesis of no significant effect of firm size on the relationship between timeliness of accounting information and financial performance of quoted banks in Nigeria.

\subsection{DISCUSSION}

Based on our results, we can confidently say that the price earnings ratio is positively and significantly affected by relevance of accounting information (beta $=0.26491)$ with $\mathrm{p}$-value $(0.0313)$ which is consistent with our $a$ priori expectation. The result implies that an increase in relevance of accounting information would increase the price earnings ratios of quoted banks in Nigeria. Similarly, there is a significant positive effect of timeliness of accounting information on price earnings ratio (beta $=0.07641)$ with $(\mathrm{p}$-value $=0.0452$ ). This implies that long audit report lag increases price earnings ratio and vice versa. Thus, the results provide evidence that earnings and book values are significant factors in the valuation of quoted banks during the 2007-2016 periods, this is consistent with the Statement of Financial Accounting Concepts No. 8 of 2010 that accounting information is value relevant when it can be used to predict, confirm or correct past predictions, as well as the findings of most of extant studies including Olugbenga and Atanda (2014) studied the value relevance of accounting information of quoted companies in Nigeria. The outcome of the study revealed that accounting information on quoted companies in Nigeria is value relevant.Also, Oyerinde (2011) investigated the value relevance of accounting data in the stock market. The findings of the study show that significant relationship exist between accounting information and share prices of the listed firms.

Our result however contradicts the findings of some scholars: Mironiuc et al. (2015) who documented a negative and insignificant effect of RVAI and PER as well as the report of Sharma, Kumar and Singh (2012) who stated that there was a decline in the value relevance of accounting information. Thus, for quoted banks to increase their price earnings and by extension, increase the market value of their stock, relevant and timely accounting information should be reported. This is backed up by value relevance theory and signaling theory.

The results show that relevance of accounting information and timeliness of accounting information have negative effects on earnings yield of quoted banks in Nigeria. The results totally disagree with our a priori expectation for all the variables. The negative effect exhibited by relevance of accounting information suggests that earnings and book value of equity predictive ability does not necessarily affect the earnings yield of quoted banks. This is consistent with the findings of most of extant studies includingAbayadeera (2010) who documented a declining value relevance of accounting information. Equally, the negative effect of timeliness of accounting information on earnings yield implies that long audit report lag reduces earnings yield of quoted banks. This suggests that good news firms (measured by earnings yield) release their annual reports earlier than bad news firms. Our result is backed up by internal reporting hypothesis and also supports the findings of Also, Dabor and Mohammed (2015) examined the determinants of audit report timeliness for listed joint stock companies in Saudi Arabia. The findings showed a negative relationship between audit report timeliness and firm performance.

For the dividend yield, the study revealed that dividend yield is negatively and significantly affected by relevance of accounting information (beta $=-0.0041$ ) with p-value $(0.0067)$ which is inconsistent with our $a$ priori expectation. The result implies that an increased earnings and book value of equity predictive ability would reduce the dividend yield of quoted banks in Nigeria since dividend is dependent on management's capital allocation decision and not necessarily on the expectations and predictions of the investors. However, this finding supports the findings of prior researchers like Sharma, Kumar and Singh (2012). Conversely, the result revealed that dividend yield is positively and significantly affected by timeliness of accounting information (measured by ARL) which is consistent with our a priori expectation. This suggests that the longer the audit report lag, the higher the dividend yield and vice versa. We established therefore that although investor's expectations and predictions do not necessarily forecast dividend payment with accuracy due to management's influence, timely availability of accounting information can reduce the uncertainty imbedded in the forecast. 


\subsection{IMPLICATION TO RESEARCH AND PRACTICE}

Our empirical outcome provides evidence that the explanatory power of financial reporting quality affects and influences banks financial performance and that accounting information is value relevant and when reported timely can be employed for the prediction of future stock prices, earnings and dividend as well as correction of past predictions by investors and analysts; also for policy makers, regulators, practitioners and academics it provides a platform for the evaluation of accounting standards as well as for the investigation of the economic consequences of new accounting standards on the performance of quoted banks in Nigeria.

\section{CONCLUSION}

The main focus of this study was to empirically investigate the effect of financial reporting quality on financial performance of quoted banks in Nigeria under the panel data framework using secondary data spanning from 2007 to 2016 . However, this study suggests that our result should not be taken without further analysis of the reinvestment policy and dividend growth which affect the dividend policy of quoted banks in Nigeria.

From the findings above, the researchers recommend as follows:

1. Ethical standards should be observed by managers in the preparation and presentation of financial statements in order to ensure that the information content of general-purpose financial statements prepared by DMBs in Nigeria are allied with its stock market value.

2. Policy makers such as SEC, CBN, and FRCN should look into the audit report lag of quoted financial institutions in Nigeria and formulate policies to enforce compliance with the stipulated reporting requirements. This will assist in restoring investors' confidence in financial reporting.

\subsection{FUTURE RESEARCH}

The study of predictive ability of current earnings and book value of equity could be applied in predicting other elements of accounting information like future cash flows; study on timeliness of accounting focused on effect of audit lag on financial performance of banks in Nigeria which established there is a trend in audit delay over time; future study could be undertaken to determine whether there are firm specific influences responsible for the delay over time, and its effect on cost of capital. This study only examined the banking industry of the Nigerian economy. However, future research could evaluate other sectors of the Nigerian economy adopting similar methodology.

\subsection{CONTRIBUTION TO KNOWLEDGE}

The study contributes to knowledge by extending the emerging academic literature on value relevance of accounting information in the developing economies. Secondly, the outcome of the research provides a platform for the evaluation of accounting standards as well as for the investigation of the economic consequences of new accounting standards on the performance of quoted banks in Nigeria. Thirdly, the study increase knowledge through formulation of an underlying econometric model for financial reporting quality and banks' financial performance as stated in the model specification.

\section{REFERENCES}

Abayedeera, N. (2010). Value relevance of information in hi-tech industries in Australia: Accounting information and intangible assets disclosure. Global Review of Accounting and Finance, 1(1), 77-99.

Abubakar, S. (2011). Value relevance of accounting information of listed new economy firms in Nigeria: An empirical investigation using Ohlson model. Paper presented at the International Conference on Accounting and Finance in Africa organised by the Department of Accounting and Finance, University of Ghana in collaboration with the Department of Accounting and Finance, University of Birmingham, UK.

Ball, R. and Brown, P., (1968). An Empirical evaluation of accounting income numbers. Journal of Accounting Research, 6(2), 159-178.

Barth, M., Landsman W. \& Lang M. (2008). International accounting standards and accounting quality, Journal of Accounting Research, 46(3), 467-498.

Barth, M. E., Beaver, W. H. \&Landsman W. R. (2001). The relevance of the value relevance literature for financial accounting standard setting: Another View. Journal of Accounting and Economics, 31, 77-104.

Beaver, W. H. (1968). The information content of annual earnings announcements.Journal of Accounting Research, Supplement,67-92. 
Beisland, L. A. (2008). Essays on the value relevance of accounting information. (Ph. D dissertation). Norwegian School of Economics and Business Administration, Bergen, Norway.

Dabor, A. O., \&Mohammed, F. (2015). Determinants of audit delay in banking sector. Fountain Journal of Management \& Social Sciences, 4(1), 74-91.

Francis, J., R. LaFond, P. Olsson \& Schipper (2002). The market pricing of earning quality. Working paper, Duke University.

Glezakos, M. Mylonakis, J. \&Kafouros, C. (2012). The Impact of Accounting Information on Stock Prices: Evidence from the Athens Stock Exchange.International Journal of Economics and Finance, 4(2), 56-68.

International Accounting Standard Board (2008). The objective of financial reporting and qualitative characteristics of decision-useful financial reporting information. Exposure draft on an improved Conceptual framework for financial reporting, London.

Jha, S., \&Hui, X. (2012). A comparison of financial performance of commercial banks: A case study of Nepal. African Journal of Business Management, 6(25), 7601-7611.

Kothari, S. P. \&J. Zimmerman (1995). Price and Return models. Journal of Accounting and Economics, (21), $155-192$

Mironiuc, M., Carp, M. \&Chersan, I. C. (2015). The relevance of financial reporting on the performance of quoted Romanian companies in the context of adopting the IFRS. Procedia Economics and Finance, (20), 404413.

Ohlson, J. A. (1995). Earnings, book values, and dividends in equity valuation. Contemporary Accounting Research, (11), 661-687.

Olugbenga, A. A., \& Atanda, O. A. (2014). The relationship between financial accounting information and market values of quoted firms in Nigeria. Global Journal of Contemporary Research in Accounting, Auditing and Business Ethics (GJCRA), 1(1), 22 -39.

Oyerinde, D. T. (2011). Value-relevance of accounting information in the Nigerian stock market.A (PhD thesis, Covenant University, Kampala.

Pervan, I. (2012). Utilization of accounting information for decision making in Croatian SME: Preliminary findings. The Business Review, Cambridge, 19 (2), 165-171.

Salim, S. B. (2012). The relationship between size and financial performance of commercial banks in Kenya. An unpublished MBA project, University of Nairobi.

Sengupta, P. (1998). Corporate disclosure quality and the cost of debt. The Accounting Review, (73), 459 - 479.

Sharma, A.K., Kumar, S. \& Singh, R. (2012). Value relevance of financial reporting and its impact on stock prices: Evidence from India. South Asian Journal of Management, 19(2), 60-77.

Uwuigbe, U., Uwuigbe, O. \& Durodola, M. (2017). IFRS adoption and value relevance of accounting information in Nigeria. International Journal of Economics and Financial Issues, 7(3), 1-8. 


\section{APPENDIX}

\section{PRICE EARNINGS RATIO RESULTS}

Dependent Variable: PER

Method: Panel EGLS (Cross-section weights)

Date: 08/05/18 Time: 23:44

Sample: 20072016

Periods included: 10

Cross-sections included: 15

Total panel (unbalanced) observations: 149

Linear estimation after one-step weighting matrix

White cross-section standard errors \& covariance (d.f. corrected)

\begin{tabular}{|c|c|c|c|c|}
\hline Variable & Coefficient & Std. Error & t-Statistic & Prob. \\
\hline $\mathrm{C}$ & 18.11444 & 0.654028 & 27.69673 & 0.0000 \\
\hline RELEVANCE & 0.264905 & 0.121716 & 2.176409 & 0.0313 \\
\hline \multicolumn{5}{|c|}{ Effects Specification } \\
\hline \multicolumn{5}{|c|}{ Cross-section fixed (dummy variables) } \\
\hline \multicolumn{5}{|c|}{ Weighted Statistics } \\
\hline R-squared & 0.267105 & \multirow{5}{*}{\multicolumn{2}{|c|}{$\begin{array}{l}\text { Mean dependent var } \\
\text { S.D. dependent var } \\
\text { Sum squared resid } \\
\text { Durbin-Watson stat }\end{array}$}} & 62.42358 \\
\hline Adjusted R-squared & 0.184447 & & & 71.61270 \\
\hline S.E. of regression & 68.85133 & & & 630487.2 \\
\hline F-statistic & 3.231467 & & & 2.068544 \\
\hline Prob(F-statistic) & 0.000143 & & & \\
\hline \multicolumn{5}{|c|}{ Unweighted Statistics } \\
\hline R-squared & 0.122115 & \multirow{2}{*}{\multicolumn{2}{|c|}{$\begin{array}{l}\text { Mean dependent var } \\
\text { Durbin-Watson stat }\end{array}$}} & 18.12752 \\
\hline Sum squared resid & 790144.7 & & & 2.509688 \\
\hline
\end{tabular}

Dependent Variable: PER

Method: Panel EGLS (Cross-section weights)

Date: 08/05/18 Time: 23:52

Sample: 20072016

Periods included: 10

Cross-sections included: 15

Total panel (unbalanced) observations: 148

Linear estimation after one-step weighting matrix

\begin{tabular}{crrrr}
\hline \hline Variable & Coefficient & Std. Error & t-Statistic & Prob. \\
\hline \hline C & 21.67619 & 26.58107 & 0.815475 & 0.4163 \\
RELEVANCE & 0.301586 & 0.128725 & 2.342876 & 0.0206 \\
FIRMSIZE & -0.126711 & 0.967859 & -0.130919 & 0.8960
\end{tabular}

Effects Specification

Cross-section fixed (dummy variables)

\begin{tabular}{llll}
\hline \hline & \multicolumn{2}{l}{ Weighted Statistics } & \\
\hline \hline R-squared & 0.275277 & Mean dependent var & 57.60704 \\
Adjusted R-squared & 0.186762 & S.D. dependent var & 69.56501
\end{tabular}




\begin{tabular}{llll}
\hline S.E. of regression & 65.83205 & Sum squared resid & 567735.5 \\
F-statistic & 3.109925 & Durbin-Watson stat & 2.344166 \\
Prob(F-statistic) & 0.000175 & & \\
\hline \hline & Unweighted Statistics & \\
\hline \hline R-squared & 0.122497 & Mean dependent var & 18.20919 \\
Sum squared resid & 789671.7 & Durbin-Watson stat & 2.508697 \\
\hline \hline
\end{tabular}

Dependent Variable: PER

Method: Panel EGLS (Cross-section random effects)

Date: 08/06/18 Time: 00:18

Sample: 20072016

Periods included: 10

Cross-sections included: 15

Total panel (unbalanced) observations: 149

Swamy and Arora estimator of component variances

White cross-section standard errors \& covariance (d.f. corrected)

\begin{tabular}{lrrrr}
\hline \multicolumn{1}{c}{ Variable } & Coefficient & Std. Error & t-Statistic & Prob. \\
\hline \multicolumn{1}{c}{ C } & -15.77843 & 20.38089 & -0.774178 & 0.4401 \\
\multicolumn{1}{c}{ AUDLAG } & 0.385992 & 0.311845 & 1.237767 & 0.2178 \\
\hline \hline & Effects Specification & & \\
& & & S.D. & Rho \\
\hline \hline Cross-section random & & & 15.42844 & 0.0397 \\
Idiosyncratic random & & & 75.89009 & 0.9603 \\
\hline \hline & Weighted Statistics & 15.25067 \\
\hline \hline R-squared & 0.027404 & Mean dependent var & 76.62033 \\
Adjusted R-squared & 0.020787 & S.D. dependent var & 845100.3 \\
S.E. of regression & 75.82204 & Sum squared resid & 2.284401 \\
F-statistic & 4.141837 & Durbin-Watson stat & \\
Prob(F-statistic) & 0.043633 & & 18.12752 \\
\hline \hline & Unweighted Statistics & 2.199610 \\
\hline \hline
\end{tabular}

Dependent Variable: PER

Method: Panel EGLS (Cross-section weights)

Date: 08/06/18 Time: 00:21

Sample (adjusted): 20082016

Periods included: 9

Cross-sections included: 15

Total panel (unbalanced) observations: 132

Iterate coefficients after one-step weighting matrix

White cross-section standard errors \& covariance (d.f. corrected)

Convergence achieved after 12 total coef iterations

\begin{tabular}{ccccc}
\hline \hline Variable & Coefficient & Std. Error & t-Statistic & Prob. \\
\hline \hline $\mathrm{C}$ & -0.582687 & 30.78321 & -0.018929 & 0.9849
\end{tabular}




\begin{tabular}{|c|c|c|c|c|}
\hline AUDLAG & 0.083708 & 0.044519 & 1.880252 & 0.0626 \\
\hline FIRMSIZE & 0.438737 & 1.017696 & 0.431108 & 0.6672 \\
\hline $\mathrm{AR}(1)$ & -0.221225 & 0.043016 & -5.142825 & 0.0000 \\
\hline \multicolumn{5}{|c|}{ Effects Specification } \\
\hline \multicolumn{5}{|c|}{ Cross-section fixed (dummy variables) } \\
\hline \multicolumn{5}{|c|}{ Weighted Statistics } \\
\hline R-squared & 0.430501 & \multirow{5}{*}{\multicolumn{2}{|c|}{$\begin{array}{l}\text { Mean dependent var } \\
\text { S.D. dependent var } \\
\text { Sum squared resid } \\
\text { Durbin-Watson stat }\end{array}$}} & 61.58693 \\
\hline Adjusted R-squared & 0.345576 & & & 78.80343 \\
\hline S.E. of regression & 60.72479 & & & 420375.0 \\
\hline F-statistic & 5.069180 & & & 2.073224 \\
\hline Prob(F-statistic) & 0.000000 & & & \\
\hline \multicolumn{5}{|c|}{ Unweighted Statistics } \\
\hline R-squared & 0.150836 & \multirow{2}{*}{\multicolumn{2}{|c|}{$\begin{array}{l}\text { Mean dependent var } \\
\text { Durbin-Watson stat }\end{array}$}} & 18.75136 \\
\hline Sum squared resid & 754576.3 & & & 2.188938 \\
\hline Inverted AR Roots & \multicolumn{3}{|l|}{-.22} & \\
\hline
\end{tabular}

\section{EARNINGS YIELD RESULTS}

Dependent Variable: ENY

Method: Panel EGLS (Cross-section weights)

Date: 08/06/18 Time: 01:30

Sample: 20072016

Periods included: 10

Cross-sections included: 15

Total panel (balanced) observations: 150

Linear estimation after one-step weighting matrix

White cross-section standard errors \& covariance (d.f. corrected)

\begin{tabular}{|c|c|c|c|c|}
\hline Variable & Coefficient & Std. Error & t-Statistic & Prob. \\
\hline $\mathrm{C}$ & -0.427587 & 0.034251 & -12.48402 & 0.0000 \\
\hline RELEVANCE & -0.006704 & 0.002573 & -2.605869 & 0.0102 \\
\hline \multicolumn{5}{|c|}{ Effects Specification } \\
\hline \multicolumn{5}{|c|}{ Cross-section fixed (dummy variables) } \\
\hline \multicolumn{5}{|c|}{ Weighted Statistics } \\
\hline R-squared & 0.143797 & \multirow{5}{*}{\multicolumn{2}{|c|}{$\begin{array}{l}\text { Mean dependent var } \\
\text { S.D. dependent var } \\
\text { Sum squared resid } \\
\text { Durbin-Watson stat }\end{array}$}} & 3.139488 \\
\hline Adjusted R-squared & 0.047954 & & & 14.08501 \\
\hline S.E. of regression & 13.55966 & & & 24637.83 \\
\hline F-statistic & 1.500335 & & & 2.286704 \\
\hline Prob(F-statistic) & 0.113453 & & & \\
\hline \multicolumn{5}{|c|}{ Unweighted Statistics } \\
\hline R-squared & 0.106160 & \multirow{2}{*}{\multicolumn{2}{|c|}{$\begin{array}{l}\text { Mean dependent var } \\
\text { Durbin-Watson stat }\end{array}$}} & -0.427587 \\
\hline Sum squared resid & 32112.05 & & & 2.385545 \\
\hline
\end{tabular}


Dependent Variable: ENY

Method: Panel EGLS (Cross-section random effects)

Date: 08/06/18 Time: 01:32

Sample: 20072016

Periods included: 10

Cross-sections included: 15

Total panel (balanced) observations: 150

Swamy and Arora estimator of component variances

White cross-section standard errors \& covariance (d.f. corrected)

\begin{tabular}{|c|c|c|c|c|}
\hline Variable & Coefficient & Std. Error & t-Statistic & Prob. \\
\hline $\mathrm{C}$ & -0.427587 & 1.796755 & -0.237977 & 0.8122 \\
\hline \multirow[t]{3}{*}{ RELEVANCE } & -0.058907 & 0.112859 & -0.521953 & 0.6025 \\
\hline & \multirow{2}{*}{\multicolumn{2}{|c|}{ Effects Specification }} & & \\
\hline & & & S.D. & Rho \\
\hline \multirow{3}{*}{$\begin{array}{l}\text { Cross-section random } \\
\text { Idiosyncratic random }\end{array}$} & & & 2.263472 & 0.0209 \\
\hline & & & 15.47697 & 0.9791 \\
\hline & \multicolumn{3}{|c|}{ Weighted Statistics } & \\
\hline R-squared & 0.001144 & \multirow{5}{*}{\multicolumn{2}{|c|}{$\begin{array}{l}\text { Mean dependent var } \\
\text { S.D. dependent var } \\
\text { Sum squared resid } \\
\text { Durbin-Watson stat }\end{array}$}} & -0.388093 \\
\hline Adjusted R-squared & -0.005605 & & & 15.38212 \\
\hline S.E. of regression & 15.42517 & & & 35214.49 \\
\hline F-statistic & 0.169485 & & & 2.173952 \\
\hline \multirow[t]{2}{*}{ Prob(F-statistic) } & 0.681165 & & & \\
\hline & \multicolumn{3}{|c|}{ Unweighted Statistics } & \\
\hline R-squared & 0.001254 & \multirow{2}{*}{\multicolumn{2}{|c|}{ Mean dependent var }} & -0.427587 \\
\hline Sum squared resid & 35880.90 & & Durbin-Watson stat & 2.133576 \\
\hline
\end{tabular}

Dependent Variable: ENY

Method: Panel EGLS (Cross-section weights)

Date: 08/06/18 Time: 01:36

Sample: 20072016

Periods included: 10

Cross-sections included: 15

Total panel (balanced) observations: 150

Linear estimation after one-step weighting matrix

White cross-section standard errors \& covariance (d.f. corrected)

\begin{tabular}{|c|c|c|c|c|}
\hline Variable & Coefficient & Std. Error & t-Statistic & Prob. \\
\hline $\mathrm{C}$ & -0.415711 & 0.107844 & -3.854731 & 0.0002 \\
\hline AUDLAG & -0.000134 & 0.001204 & -0.111561 & 0.9113 \\
\hline \multicolumn{5}{|c|}{ Effects Specification } \\
\hline \multicolumn{5}{|c|}{ Cross-section fixed (dummy variables) } \\
\hline \multicolumn{5}{|c|}{ Weighted Statistics } \\
\hline R-squared & 0.128538 & \multicolumn{2}{|c|}{ Mean dependent var } & 2.207265 \\
\hline Adjusted R-squared & 0.030986 & \multicolumn{2}{|c|}{ S.D. dependent var } & 12.50867 \\
\hline S.E. of regression & 12.38040 & \multicolumn{2}{|c|}{ Sum squared resid } & 20538.76 \\
\hline F-statistic & 1.317637 & \multicolumn{2}{|c|}{ Durbin-Watson stat } & 2.219220 \\
\hline
\end{tabular}




\begin{tabular}{|c|c|c|c|c|}
\hline \multicolumn{5}{|l|}{ Prob(F-statistic) } \\
\hline \multicolumn{5}{|c|}{ Unweighted Statistics } \\
\hline R-squared & 0.105993 & Mean depende & it var & -0.427587 \\
\hline Sum squared resid & 32118.05 & Durbin-Watsor & stat & 2.385736 \\
\hline \multirow{9}{*}{\multicolumn{5}{|c|}{$\begin{array}{l}\text { Dependent Variable: ENY } \\
\text { Method: Panel EGLS (Cross-section weights) } \\
\text { Date: } 08 / 06 / 18 \text { Time: } 01: 38 \\
\text { Sample: } 20072016 \\
\text { Periods included: } 10 \\
\text { Cross-sections included: } 15 \\
\text { Total panel (unbalanced) observations: } 149 \\
\text { Linear estimation after one-step weighting matrix } \\
\text { White cross-section standard errors \& covariance (d.f. corrected) }\end{array}$}} \\
\hline & & & & \\
\hline & & & & \\
\hline & & & & \\
\hline & & & & \\
\hline & & & & \\
\hline & & & & \\
\hline & & & & \\
\hline & & & & \\
\hline Variable & Coefficient & Std. Error & t-Statistic & Prob. \\
\hline $\mathrm{C}$ & 2.100813 & 1.458203 & 1.440687 & 0.1520 \\
\hline AUDLAG & -0.000120 & 0.001296 & -0.092594 & 0.9264 \\
\hline FIRMSIZE & -0.091850 & 0.051533 & -1.782363 & 0.0770 \\
\hline \multicolumn{5}{|c|}{ Effects Specification } \\
\hline \multicolumn{5}{|c|}{ Cross-section fixed (dummy variables) } \\
\hline \multicolumn{5}{|c|}{ Weighted Statistics } \\
\hline R-squared & 0.131123 & \multirow{5}{*}{\multicolumn{2}{|c|}{$\begin{array}{l}\text { Mean dependent var } \\
\text { S.D. dependent var } \\
\text { Sum squared resid } \\
\text { Durbin-Watson stat }\end{array}$}} & 2.127141 \\
\hline Adjusted R-squared & 0.025804 & & & 12.50303 \\
\hline S.E. of regression & 12.41737 & & & 20353.22 \\
\hline F-statistic & 11.245010 & & & 2.220643 \\
\hline Prob(F-statistic) & 0.002875 & & & \\
\hline \multicolumn{5}{|c|}{ Unweighted Statistics } \\
\hline R-squared & 0.106022 & Mean depende & it var & -0.431570 \\
\hline Sum squared resid & 32116.69 & Durbin-Watsor & stat & 2.385429 \\
\hline
\end{tabular}

\section{Dividend Yield ResultS}

Dependent Variable: DIVY

Method: Panel Least Squares

Date: 08/05/18 Time: 03:09

Sample: 20072016

Periods included: 10

Cross-sections included: 15

Total panel (balanced) observations: 150

White period standard errors \& covariance (d.f. corrected)

\begin{tabular}{crrrr}
\hline \hline Variable & Coefficient & Std. Error & t-Statistic & Prob. \\
\hline \hline C & 0.082433 & $1.74 \mathrm{E}-18$ & $4.75 \mathrm{E}+16$ & 0.0000 \\
RELEVANCE & -0.004131 & 0.001498 & -2.758309 & 0.0066 \\
\hline \hline
\end{tabular}

Cross-section fixed (dummy variables) 


\begin{tabular}{lllr} 
R-squared & 0.173263 & Mean dependent var & 0.082433 \\
Adjusted R-squared & 0.080718 & S.D. dependent var & 0.139951 \\
S.E. of regression & 0.134184 & Akaike info criterion & -1.078670 \\
Sum squared resid & 2.412721 & Schwarz criterion & -0.757535 \\
Log likelihood & 96.90024 & Hannan-Quinn criter. & -0.948203 \\
F-statistic & 1.872196 & Durbin-Watson stat & 2.495553 \\
Prob(F-statistic) & 0.031272 & & \\
\hline \hline
\end{tabular}

Dependent Variable: DIVY

Method: Panel EGLS (Cross-section weights)

Date: 08/05/18 Time: 03:05

Sample: 20072016

Periods included: 10

Cross-sections included: 15

Total panel (unbalanced) observations: 149

Linear estimation after one-step weighting matrix

White period standard errors \& covariance (d.f. corrected)

WARNING: estimated coefficient covariance matrix is of reduced rank

\begin{tabular}{lrrrr}
\hline \hline \multicolumn{1}{c}{ Variable } & Coefficient & Std. Error & t-Statistic & Prob. \\
\hline C & 0.181303 & 0.161132 & 1.125180 & 0.2626 \\
RELEVANCE & -0.002757 & 0.000953 & -2.893017 & 0.0045 \\
FIRMSIZE & -0.003588 & 0.005869 & -0.611448 & 0.5420 \\
\hline \hline \multicolumn{5}{c}{ Effects Specification } \\
\hline \hline Cross-section fixed (dummy variables) & & \\
\hline \hline & Weighted Statistics & \\
\hline \hline R-squared & 0.311100 & Mean dependent var & 0.164445 \\
Adjusted R-squared & 0.227597 & S.D. dependent var & 0.180456 \\
S.E. of regression & 0.131893 & Sum squared resid & 2.296230 \\
F-statistic & 3.725621 & Durbin-Watson stat & 2.471531 \\
Prob(F-statistic) & 0.000012 & & \\
\hline \hline
\end{tabular}

Dependent Variable: DIVY

Method: Panel EGLS (Cross-section weights)

Date: 08/05/18 Time: 05:23

Sample (adjusted): 20082016

Periods included: 9

Cross-sections included: 15

Total panel (balanced) observations: 135

Iterate coefficients after one-step weighting matrix

White cross-section standard errors \& covariance (d.f. corrected)

Convergence achieved after 9 total coef iterations

\begin{tabular}{crrrr}
\hline \hline Variable & Coefficient & Std. Error & t-Statistic & Prob. \\
\hline \hline C & 0.041847 & 0.009738 & 4.297231 & 0.0000 \\
AUDLAG & 0.000480 & 0.000113 & 4.250530 & 0.0000 \\
AR(1) & -0.320393 & 0.074639 & -4.292580 & 0.0000
\end{tabular}




\begin{tabular}{llll}
\hline \hline \multicolumn{4}{c}{ Effects Specification } \\
\hline \hline Cross-section fixed (dummy variables) & & \\
\hline \hline \multicolumn{4}{c}{ Weighted Statistics } \\
\hline \hline R-squared & 0.441267 & Mean dependent var & 0.170196 \\
Adjusted R-squared & 0.365507 & S.D. dependent var & 0.168555 \\
S.E. of regression & 0.138171 & Sum squared resid & 2.252757 \\
F-statistic & 5.824515 & Durbin-Watson stat & 1.977113 \\
Prob(F-statistic) & 0.000000 & & \\
\hline \hline & Unweighted Statistics & 0.085081 \\
\hline \hline R-squared & 0.189154 & Mean dependent var & 2.136910 \\
Sum squared resid & 2.342511 & Durbin-Watson stat & \\
\hline \hline Inverted AR Roots & -.32 & & \\
\hline \hline
\end{tabular}

Dependent Variable: DIVY

Method: Panel EGLS (Cross-section weights)

Date: 08/05/18 Time: 06:31

Sample (adjusted): 20082016

Periods included: 9

Cross-sections included: 15

Total panel (unbalanced) observations: 134

Iterate coefficients after one-step weighting matrix

White cross-section standard errors \& covariance (d.f. corrected)

Convergence achieved after 11 total coef iterations

\begin{tabular}{ccccc}
\hline \hline Variable & Coefficient & Std. Error & t-Statistic & Prob. \\
\hline \hline C & 0.129943 & 0.093262 & 1.393305 & 0.1662 \\
AUDLAG & 0.000421 & 0.000114 & 3.705230 & 0.0003 \\
ARMSIZE & -0.002999 & 0.003311 & -0.905667 & 0.3670 \\
\hline \hline & -0.314933 & 0.081679 & -3.855722 & 0.0002 \\
\hline \hline Cross-section fixed (dummy variables) & & & \\
\hline \hline & Effects Specification & & \\
\hline \hline R-squared & Weighted Statistics & & \\
Adjusted R-squared & 0.436063 & Mean dependent var & 0.164832 \\
S.E. of regression & 0.353417 & S.D. dependent var & 2.131519 \\
F-statistic & 0.135555 & Sum squared resid & 2.009125 \\
Prob(F-statistic) & 5.276270 & Durbin-Watson stat & \\
\hline \hline & 0.000000 & & 2.139612 \\
\hline \hline
\end{tabular}

